\title{
Consumer Legal Protection on Online Buying and Selling
}

\author{
Puguh Yuli Setiawan ${ }^{1}$, Faisal Santiago ${ }^{2}$ \\ University of Borobudur, Jl. Pemuda, RT.1/RW.3, Rawamangun, Kec. Pulo Gadung, DKI \\ Jakarta 13220, Indonesia ${ }^{1,2}$ \\ \{puguhyuli.work@gmail.com¹,faisalsantiago@borobudur.ac.id²
}

\begin{abstract}
The era of digitalisation and pandemic conditions allows people to shop for daily necessities without having to leave the house with just a smartphone can buy the desired item. This paper uses normative legal research methods to review written regulations so that this research is closely related to libraries for secondary data sources. The conclusion of this study is the regulation contained in Law No. 8 of 1999 on consumer protection and Law No. 19 of 2016 on Information and Electronic Transactions has not been able to protect consumers because the provisions listed in this law have not accommodated the rights of consumers in online transactions.
\end{abstract}

Keywords: Consumer Protection; Electronic Transactions; Consumer

\section{Introduction}

Advances in science make technology always new, without exception in the field of telecommunications, especially internet media. Such developments make the wiggle room of goods and/or services transactions cross the borders of a country's territory freely. Such conditions support the effects of more expansive economic growth in the world. Indonesia also feels the impact so that the development of goods and / services' flow become easily obtained, especially those who benefit from consumers.

In the era of globalisation, when the boundaries of a country will become blurred, on the one hand, the relationship between the national economy and the international economy will be closer. On the other hand, globalisation's current conditions can result in businesses and consumers' position being unbalanced. Consumers can become the object of businesses' business activities through advertising, promotions, sales methods, and the implementation of standard agreements that harm consumers.

Manufacturers or businesses will seek the highest profit under economic principles. Prasasto presents four examples of elements that affect unhealthy business behaviour: conglomerates, cartels/trusts, insider trading, and unfair/fraudulent competition. There are at least four forms of deeds born due to unhealthy business practices such as the above, namely raising prices, lowering quality, dumping and falsifying products.

Concerning these matters, the consumer needs to be legally protected from possible losses caused by such fraudulent business practices. Therefore, regulations are required, for example, on how to make good and healthy food, and rules that protect consumers from losses arising 
from using or consuming food and strict supervision for those regulations to be adhered to and implemented. With the understanding that all people are consumers, protecting consumers means also protecting the whole community. Therefore, under the mandate of Paragraph IV of the Opening of the Republic of Indonesia's Constitution in 1945, consumer protection becomes important (Supriyanto, 2020).

Consumer protection law today gets quite an attention because it concerns society's welfare, not only the community as consumers who get protection, each has rights and obligations. The government plays a role in regulating, supervising, and controlling to create a conducive system interconnected. Thus the goal of the welfare of society at large can be achieved.

Business is synonymous with the presence of customers. There is part of the interaction in carrying out economic or business activities and is usually referred to as consumers, namely connoisseurs of products produced by business people or companies. In society, people are never separated from conflicts or disputes concerning violations of consumer rights. Moreover, in business activities, there needs to be protected, especially consumers. Everyone who uses goods and services available in the community, whether for their benefit, family, others, or other creatures, is not traded. The legal basis of consumer protection is Number 8 , the Year 1999 (Santiago, 2016).

Internet as a medium of information and electronic communication has been widely utilised for various activities, browsing (browsing, surfing), searching for data and news, sending messages to each other via e-mail and trade. Trading activities by utilising internet media is known as electronic commerce or e-commerce for short. In this era of globalisation, the development of information and communication technology is running rapidly along with the pace of national development in all fields, demanding that people move quickly and efficiently in meeting the needs of their lives. The rapid growth that occurs in all these areas encourages people to improve their mobility further dynamically and rapidly so that they can obtain information in a short time. Sources of information that the public often uses, in general, are print media, namely newspapers, magazines, tabloids, and electronic media in the form of television, radio, and the internet.

With advertising, businesses will find an easy way to promote the goods and services they produce, and in that way, they will also be able to run their business smoothly with a variety of large profits earned. Sometimes, companies often justify all means in promoting the goods and services offered to consumers with the intention that consumers are interested and interested to buy so that businesses will reap a significant profit. For example, companies often promote the goods and services offered with too excessive information, and the information submitted is not under the conditions and circumstances of the original product.

\section{Methods}

Research methods as an effective way of finding scientific truths are the author's concerning aspects of methods that include thinking to find a purpose. In this type of research, it is development research with a descriptive approach. Furthermore, the method of procedure that the author uses is normative legal research that is legal research conducted by researching library materials or secondary data. The legal materials are organised systematically, reviewed and then drawn a conclusion concerning the problem being examined.

In a study must be disclosed the type of data used is a type of secondary data where data obtained from sources whose data properties have been documented by other parties. Data 
collection for normative law research, writing use with literature study method. In this case, the author must be observant and precise to find the data in the legislation and in the literature that has a relationship with the problem that the author examines. Researchers conduct data processing in a qualitative way that is a method of data analysis that does not display numbers as a result of research but is presented in the form of discussion with a description of sentences and presented in writing.

\section{Discussion}

\section{1 consumer}

The term consumer comes from and translates from the word consumer (EnglishAmerican) or konsument (Dutch). The meaning of the word consumer is (the opposite of the manufacturer), everyone who uses the goods. The purpose of the use of these goods and services will determine which consumer the user belongs to. Similarly, English-Indonesian Dictionary gives the meaning of the word consumer as a user or consumer.

Business is synonymous with the presence of customers. There is part of the interaction in carrying out economic or business activities and is usually referred to as consumers, namely connoisseurs of products produced by business people or companies (Santiago, 2012: 79). Every user of goods and services available in the community, whether for his benefit, family, others, or other creatures and not for trade.

The Consumer Protection Law explains that consumer understanding can be divided into three parts, namely: 1) Consumers in the general sense of users, users and utilisation of goods and services for specific purposes, 2) Consumers between, i.e. users, users and utilisation of goods and services to be produced into other goods/services or to trade them, for commercial purposes. This consumer is the same as the business, and 3) The end consumer, namely the user, user, and utilisation of consumer goods and services to meet the needs of themselves, family or household, is not to be traded back

The impact of the existence of the internet as a result of the information technology revolution for consumers, on the one hand, has changed consumer behaviour to be increasingly critical and selective in determining the products to be chosen. Consumers choose greater access to a wide variety of products. Similarly, for manufacturers, this progress has a positive impact in facilitating product marketing to cut distribution lines resulting in cost and time savings and make it easier for manufacturers to collect customer databases electronically and other conveniences.

\subsection{Consumer Protection}

Definition of Article 1 Number (2), Consumer Protection Law, there are the following elements:

a. Everyone, subject referred to as a consumer, means everyone who is a user of goods and services. The term person raises doubts about whether only individual people are commonly called natuurlijke persons or legal entities (rechtpersoon). In this case, the consumer's understanding should be limited to individuals and legal entities.

b. Under the explanation of Article 1 Number (2) consumer protection law, the user emphasises the consumer is the end consumer (ultimate consumer). The term user, in this case, is appropriately used in the provision while also indicating the goods or services 
used are not necessarily the result of buying and selling. Consumers always have to give their achievements by paying money to obtain goods or services.

c. Goods and services, Relating to the term goods and services, in place of the terminology used, the word product. Currently, the product has connotations of goods and services.

d. Available in the community, goods and services offered to the public are already available in the market

With the protection of consumers expected in conducting this business activity, service users do not feel harmed by the business. Consumer protection law in Indonesia has a legal basis that the government has established. With a factual legal basis, the protection of consumer rights can be done optimistically. For consumer protection arrangements have been regulated in the Consumer Protection Act. With the existing rules governing consumer protection issues, it is possible to prove upside down in disputes between consumers and businesses. Consumers who feel their rights are violated can complain and process their case legally at the Consumer Dispute Resolution Agency (BPSK). This legal basis can be a valid legal basis when it comes to consumer protection arrangements.

UUPK has not been able to protect consumers in e-commerce transactions because the provisions listed in the UUPK have not accommodated consumer rights in e-commerce transactions. There is because e-commerce has its characteristics compared to conventional transactions. The element is the non-meeting of sellers and purchase men, the media used is the internet, trades can occur across the juridical boundaries of a country, goods sold can be in the form of services/services or digital products such as software. Consumer rights in Indonesia are accommodated in Article 4 of the UUPK, namely:

a. The right to security and safety in consuming goods and services.

b. The right to choose goods or services and obtain goods and services under the exchange rate and conditions and guarantees promised.

c. The right to truthful, transparent, and honest information regarding the conditions and warranties of goods and services.

d. The right to be heard his opinions and complaints about the goods and services used.

e. The right to appropriate protection advocacy and consumer protection dispute resolution efforts.

f. The right to obtain coaching and consumer education.

g. The right to be treated or appropriately served and honestly and non-discriminatorily.

$\mathrm{h}$. The right to compensation, indemnification and reimbursement, if the goods and services received are not with the agreement or not as they should be.

i. Rights stipulated in other statutory provisions.

Based on the study results, in e-commerce transactions, consumers' rights are precarious to be violated. In this case, consumers do not get their rights in full in e-commerce transactions. These rights include:

1. The right to comfort, security and safety in consuming goods and services. Consumers do not directly identify, see and touch the goods to be ordered over the internet, as is common in face-to-face transactions in the market. Also, the right to obtain security in $e$ commerce transactions is very lacking. There is no guarantee of data security, credit card numbers, good passwords provided by merchants located in Indonesia, such as cryptocurrency techniques, SSL and SET. In contrast to a merchant who is abroad, such as Amazon.com, it guarantees consumers' security in transacting with the SSL (Secure Socket Layer) method. Or the absence of a guarantor agency (Certification Authority) for the validity of an online store, so that convenience, consumer safety in transactions has not been guaranteed. 
2. The right to correct, straightforward and honest information about the condition of an item. Business and consumers do not meet in person, and communication occurs if they actively ask the industry. In this case, the product's information is very lacking because in doing the offer, the merchant only displays product descriptions and product images on its website. There are goods sold on the internet that require more than just a product description, for example, perfume that must be tried first before buying it.

3. The right to be heard his opinions and complaints about the goods and services used. Because sellers and buyers do not meet in person, communication occurs through e-mail or phone calls and or online stores that do not list real-world addresses, making it very difficult for consumers to submit complaints. However, an online store provides a way to communicate with him to ask things that are considered unclear or complain about the products he buys. Besides, it is also challenging to prosecute businesses in cyberspace.

4. The right to proper advocacy, protection and efforts to resolve consumer protection disputes. As happens to respondents who are not sent their order goods by merchants abroad, it is challenging to sue them. It is located far abroad, and the unclear mechanism of settlement in e-commerce transactions, because these transactions cross the boundaries of a country, to determine which law is chosen is not easy. Consumers' right to obtain precise information about the identity of companies owned by businesses in transactions is indispensable, such as an exact address in the real world and the name of the owner of an online store. Such rights can't be realised in e-commerce transactions because businesses are often not listed the company's full address in the real world, usually displayed on the website only telephone number and e-mail address. There is certainly very detrimental for consumers if there is a problem in the transaction, such as goods sent not under the goods ordered, the goods ordered have not reached the hands of consumers on time. So consumers will have difficulty if they will complain to businesses. Besides, the consumer does not know clearly with whom he transacts.

Another very important but less realised right in e-commerce transactions is the right to guarantee the confidentiality of personal data belonging to consumers by businesses. The request has not been accommodated in the UUPK. Guarantee of data confidentiality is significant to be maintained by companies for the safety and convenience of consumers in transacting. If the business person acts fraudulently, then the personal data can be sold to other parties for promotional purposes.

When considered, consumer rights that the UUPK normatively regulates seem to be limited to conventional trading activities. Besides, protection is focused only on the consumer side as well as the side of the product traded, while protection from the business actors side, such as information about the identity of the company of businesses and guarantees of confidentiality of data belonging to consumers, have not been accommodated by the UUPK, even though those rights are fundamental to be regulated for consumer safety in transacting.

The limitations of UUPK to protect consumers in e-commerce transactions also appear to be limited in the scope of understanding of businesses. Article 1 paragraph (3) of this law states, what is meant by business actors is "Every individual or business entity, whether in the form of a legal entity or not a legal entity established and domiciled or conducting activities within the jurisdiction of the Republic of Indonesia, either alone or together through an agreement to conduct business activities in various economic fields".

While according to the explanation of article 1 paragraph (3), UUPK, which is included in the business actors are "business actors included in this sense are companies, corporations, socalled state-owned enterprises, cooperatives, importers, traders, distributors, and others. 
Seeing the above understanding is a very narrow scope of understanding of business actors regulated by the UUPK, where businesses regulated in this law are businesses whose working areas are in the Republic of Indonesia's territory. Whereas if seen from the characteristics of $e$ commerce, one of which is a trade that crosses the country's borders, then the understanding of business actors in this UUPK can not reach if the business actors are not in the Republic of Indonesia. However, UUPK still comes from online store businesses that do business in the Republic of Indonesia's territory.

\subsection{Legal Protection That Should Be Regulated in Electronic Transactions}

There are 4 (four) materials that need to be regulated to protect the law against consumers in e-commerce transactions, namely:

\section{a) Legal Protection from the Business Actor's Side}

1. nature of these business actors is obliged to include identity in the website, based on the research results on online store entrepreneurs, obtained online stores that only put phone numbers and e-mail addresses alone without listing the exact address of the perpetrator Saha or other identities. It is hoped that this identity listing will ensure legal certainty for the consumer transacting.

2. An online store validity guarantee agency, based on research, online stores located in Indonesia there is no guarantee of the store's validity to transact with a fictitious online store.

\section{b) Legal Protection from the Consumer Side}

There is a guarantee of consumer personal data confidentiality because other parties can trade such personal data if not kept confidential by businesses for promotional purposes.

\section{c) Legal Protection for Consumers from the Product Side}

In offering its products, businesses are required to:

1. Provide clear and complete information about the products offered so that consumers are not misled, essential information (product quality whether genuine, imitation, new, used, product type, size) in addition to other relevant information such as product excellence. There is very important to assist consumers in making decisions to buy or not. Based on the research results for businesses in Indonesia in describing the product is very minimal information, only mention the price and a little explanation about the product. As to overseas firms very clearly inform about the product and list rating poll for the product's quality, as done Amazon.com.

2. Product information about the product must be provided through language that is easy to understand and does not give rise to other interpretations. In this case, considering $e$ commerce is a trade that crosses the country's borders, and businesses can be anywhere than to use language adapted to the company's land of origin. So, in this case, demand consumers in transacting with businesses whose speech can be understood.

3. Assure that the products offered are safe or comfortable to consume or use.

4. Guarantee that the products offered are under what is promoted by businesses. 


\section{d) Legal Protection for Consumers from the Transaction Side}

Not all consumers understand how to transact through internet media, so in this case, businesses need to list clearly and entirely about the mechanism of transactions and other matters related to commerce, such as:

1. The consumer must meet the conditions in making a transaction. In this case, the consumer must meet the requirements that must be met, such as filling in personal data and the complete address on the form on the businessman's website. There is done for administrative data and to know the credibility of a consumer.

2. An opportunity for consumers to review the transactions they will make is intended to avoid consumers' mistakes. Based on research on online stores, a facility can cancel or cancel, or I'm afraid I have to disagree consumers can click that if they do not want to continue the transaction or cancel the transaction.

3. The price of the product offered, whether it includes postage or not. Usually, online store businesses add their costs for the delivery of goods. So the price of the product listed on the businessman's website does not include shipping costs.

4. Information about whether or not consumers can return purchased goods and their mechanisms. There is very important to understand by consumers because not all goods that become orders are received perfectly. There is a possibility of damage at the time of delivery, or the goods are defective production. Consumers can return the goods under the mechanisms that businesses and consumers have determined to get new goods again.

5. Dispute resolution mechanism is vital to be clearly informed by businesses to consumers, because not always is a transaction going smoothly, sometimes disputes between companies and consumers occur. So it needs to be regulated regarding dispute resolution mechanisms. Based on research, businesses in Indonesia do not include dispute resolution mechanisms. So there is no legal certainty in resolving disputes between companies and consumers.

6. A reasonable period of claim submission, in the case of filing a claim, is expected to be too short because it will harm the consumer itself if it is too short. Based on research, merchants gudangpc.com provide a deadline for returning damaged products 7 (seven) days after receipt of goods to consumers. But for merchants mybutik.com do not include the period of return of goods, here raises an uncertainty if it turns out that the goods sent are damaged or defective production when to return them.

7. Businesses must provide a recording of transactions that consumers can access at any time related to transactions that have been or are being done by consumers. The recording of this transaction can be used as evidence in court in a dispute between businesses and consumers. Based on the research results, gudangpc.com and mybutik.com merchants have a History transaction facility, where this facility can know the transactions that have been or are being done by consumers.

8. How the delivery of goods, the mechanism of delivery of goods, needs to be clearly known by the consumer. Here, consumers will choose how the goods are sent through couriers, delivery services or Cash on Delivery (COD). Based on the research results, merchants gudangpc.com and mybutik.com have a precise mechanism of delivery of goods. 


\section{Conclusion}

Consumer protection against the default of businesses in e-commerce transactions, especially in terms of regulation on consumer protection against businesses' insolvency, still needs improvement. Law No. 8 of 1999 has not been able to protect consumers in e-commerce transactions because the provisions listed in the UUPK have not accommodated the rights of consumers in this transaction. There is because e-commerce has its characteristics compared to conventional transactions that do not meet sellers and buyers.

In e-commerce transactions, consumer rights are precarious to be violated. Consumer rights that the UUPK normatively regulates seem to be limited to conventional trading activities. Besides, protection is focused only on the consumer side as well as the side of the traded product, while protection from the business side such as information about the identity of the business entity as well as guarantees of confidentiality of data belonging to consumers have not been accommodated by the UUPK, even though those rights are fundamental to be regulated for consumer security in transacting.

\section{References}

[1] Anwar, N. S. (2019). Analisis Transaksi Digital Cryptocurrency Sebagai Investasi Global Dalam Perspektif Hukum Islam (Studi Kasus Dinar Dirham di Makassar).

[2] Gordon, J. M. (1998). Business Law: An Introduction. Business Law: An Introductionby TheBusinessProfessor.Com, 501(c), 428-431.

[3] Santiago, F. (2016). Bunga Rampai Catatan Hukum. Perpustakaan Nasional RI. Katalog Dalam Terbitan.

[4] Supriyanto, Eko Eddya. 2020. Eksistensi Nilai-Nilai Pancasila Dalam Kebijakan Ekonomi Indonesia. 1st ed. Malang: Literasi Nusantara.

[5] Nababan, K. N. N. (2019). Tinjauan Legalitas Transaksi Bitcoin di Indonesia. JuristDiction, 2(5), 1745-1764. 